Article

\title{
Religious Knowledge, Ineffability and Gender
}

\author{
Roxana Baiasu ${ }^{1,2}$ \\ 1 Faculty of Philosophy, University of Oxford, Radcliffe Humanities, Woodstock Road, Oxford OX2 6GG, UK; \\ Roxana.Baiasu@philosophy.ox.ac.uk \\ 2 Stanford University Center in Oxford, Stanford House, 65 High St, Oxford OX1 4EL, UK
}

Received: 19 March 2018; Accepted: 9 May 2018; Published: 24 May 2018

\begin{abstract}
The issue of ineffability constitutes a significant challenge in the philosophy of religion. In this paper, I first argue that it is difficult to see how the traditional approach, which I call 'the metaphysical approach', can address this challenge. I consider then a post-metaphysical approach inspired by Wittgenstein which does look more promising in dealing with the ineffable. Finally, I argue that there are, however, new challenges that have to be taken into account; in particular, I focus here on the problem raised by contemporary feminist philosophers of the gendering of religious knowledge.
\end{abstract}

Keywords: ineffable understanding; epistemic situatedness; gendering of religious knowledge

\section{Introduction}

Matters of the utmost significance to us, such as the meaning of our existence, our awareness of our finitude and mortality appear to involve certain ineffable insights about ourselves and our existence in the world. But religion seems to have a special link to ineffability. Religious texts and experiences, or spiritual practices, such as prayer to God or Buddhist meditation, are often reported to involve special ineffable insights, that is, a spiritual understanding that cannot be put into words by using language in customary ways. Experiences of this kind seem to be at the core of religious experience and knowledge, in both so-called 'Analytic' and 'Continental' traditions.

Despite the significant link between ineffability and religious knowledge, the issue of ineffability has been relatively neglected by mainstream literature in philosophy of religion. As I point out below, the issue of ineffability constitutes a major challenge for traditional, dominant approaches to religious knowledge. There is, however, in recent literature a growing interest in the issue of ineffability (Moore 2003; Marion 1999; Jonas 2016; Derrida 1992, 1995, 2001; Bennett-Hunter 2014; Anderson 2012, 2002; Alston 1956).

Any attempt to talk about the ineffable is faced with a number of serious challenges. Many thinkers and believers claim that God's nature or their spiritual experiences are ineffable but then go on to speak about them. Are they then not contradicting themselves?

In this paper I consider two main challenges that an account of ineffable religious understanding can face- the first concerns the logic of the account, and the second, its methodology. First, one of the most important challenges to such an account is what I call 'the objection from inconsistency'. The attempt to speak about that which cannot be said appears to involve a sort of inconsistency, a kind of contradiction. More precisely, it faces the threat of self-stultification: the attempt to speak about that which cannot be said looks like an attempt to do the impossible, which thus undermines itself. How is it possible to respond to this objection, if at all?

The second important issue that I consider in this paper is a certain characteristic of ineffable knowledge, namely its being deeply situated, that is, being dependent on one's situation and perspective within a religious, cultural and historical context. In connection to this consideration the 
question is how, if at all, is it possible to give an appropriate philosophical account of this understanding in a way which is no longer dependent on that perspective.

\section{A Traditional, Metaphysical Approach to Religious Knowledge}

According to a classical approach, religious knowledge claims refer to a transcendent reality. This approach is thus metaphysical: it is concerned with a rich metaphysics of a transcendent realm of reality. Some philosophers prefer to call it a 'realist' approach (Anderson 1998). Religious knowledge is taken to be a form of theoretical, propositional knowledge concerned with certain facts or features of divine reality. Religious knowledge is taken to be answerable to this reality and as aiming at truth. Such a conception of religious knowledge is shared by both realist theism and atheism which debate over the existence of God or other divine being(s).

In the Western tradition, classical theist debates about the doctrine of God which have preoccupied philosophers and theologians since at least the Middle Ages (including Anselm, Aquinas, Descartes, Hume and Kant) have revived in contemporary philosophy of religion, especially in Anglo-American mainstream philosophy of religion through the work of prominent philosophers such as Swinburne, Plantinga, Alston or Mackie 1982 (Anderson 1998, p. 14). In A Feminist Philosophy of Religion, Anderson argues that despite important differences between the various ways these philosophers develop their approaches, there is a basic commonality regarding certain methodological principles which concern a reliance upon some notion of experience as a fundamental warrant of true belief (Anderson 1998, pp. 13ff). As she points out, empirical realism is the dominant approach in contemporary philosophy of religion.

Theist defenders of the metaphysical approach seek to establish, by means of formal, evidential or experiential arguments, a rational foundation or justification of religious knowledge. But, as they acknowledge on some occasions or in passing, fundamental forms of religious knowledge are ineffable. St Aquinas, for example, claimed that the ecstatic vision he had of God and which has more significance than all that he had written was ineffable.

The traditional account attempts to say a number of things about God, by elaborating arguments meant to establish theoretical claims concerning God's existence and essential characteristics, which are taken to provide a foundation or justification for religious knowledge.

\section{The Objection from Inconsistency}

The traditional account belies ineffability insofar as it appears to approach religious knowledge as if it had a fully effable content. Certain versions of this approach attempt to deal with ineffable knowledge by assuming or contending that they express what they take to be the content of ineffable knowledge. These are attempts to put into words what is known when one has that knowledge and claim to offer truths about a transcendent reality (Moore 2001). ${ }^{1}$

When it comes to ineffable religious understanding, the traditional approach appears to contradict itself. It is difficult to see how it can respond to the objection of inconsistency and, more precisely, of self-stultification: it does look like an attempt to do the impossible, that is, to put into words something which cannot be said, but only shown or indicated (Moore 2003; Derrida 1992; Marion 1999).

This criticism requires, however, a qualification: the objection of inconsistency applies to the traditional approach only insofar as this approach presupposes or accepts some kind of ineffability claim.

The traditional approach seems to draw heavily on the theoretical model of exact sciences-and in particular, on their methodological models of justification and explanation by means of formal argument and recourse to empirical evidence or some form of experience. These methodological

1 A. W. Moore develops in more detail this critique, and points out other contradictions and inconsistencies of the traditional metaphysical approach (Moore 2001). See also Anderson's related discussion in 'Ineffable Knowledge and Gender' (Anderson 2002, pp. 177-83). 
tools are used, for example, in theist debates over the existence of God. At least some versions of the traditional approach employ an empiricist methodology insofar as they take experience to be a fundamental warrant of true belief (Anderson 1998, pp. 13ff). As Anderson notes, the notions of experience used in theist debates is problematic 'because it assumes at the same time intensely subjective experiences and completely general experience frequently described as the "view from nowhere"' (Anderson 1998, p. 26).

The problem of ineffability can raise serious challenges to the traditional approach and its scientist methodology. In the next section, I consider an alternative approach and its solution to the question as to whether it is possible, if at all, to talk about the ineffable without contradiction.

\section{A Post-Metaphysical, Wittgensteinian Approach to Ineffable Knowledge}

There are a number of different post-metaphysical influential approaches in 20th Century and contemporary philosophy of religion, which include Wittgensteinian approaches in the so-called 'Analytic' tradition, and phenomenological and postmodern approaches in the 'Continental' tradition, for which the issue of ineffability has been central. In the phenomenological tradition, they have been significantly influenced by Martin Heidegger's work and, in particular, his concern to overcome metaphysics and to address issues related to religious life, some of which involve ineffable aspects (Heidegger 1977, 1992, 1998, 2010) ${ }^{2}$. Heidegger's phenomenology has influenced, for example, the theological turn in French phenomenology and postmodernism. In the area of postmodern philosophy, prominent thinkers such as Derrida $(1992,1995,2001)$ and Marion (1999) have stimulated and renewed discussions concerning ineffability, occasionally in debate with analytic philosophers; for instance, the debate between Derrida and the Oxford philosopher A. W. Moore (whose approach to the ineffable is to some extent influenced by Wittgenstein) is especially noteworthy (Glendinning 2001).

In this paper, I focus on Wittgensteinian post-metaphysical approaches. These approaches have been developed in various, sometimes conflicting ways by their proponents, but they all seem to endorse a number of Wittgenstein's main views. They endorse Wittgenstein's rejection of the claim that philosophy can offer theories which can reveal basic aspects of reality and the foundations of knowledge. The Wittgensteinian approach is in this sense anti- or post-metaphysical. It could also be called non-realist and anti-foundationalist (Anderson 1998, p. 14). Furthermore, this approach challenges the idea of scientific knowledge as the paradigm for philosophical inquiry. It also develops Wittgenstein's emphasis on the significance of our embeddedness in the world and the role of practices in the formation of our making sense of things. For example, contemporary Wittgensteinians working in the area of philosophy of religion reject the traditional view that religious knowledge is abstract or empirical theorizing about religious claims and arguments concerned with a certain transcendent reality. Religious knowledge is rather something which has a place in a form of life and is linked to religious practices. It is not theoretical knowledge of an aspect of reality; religious knowledge is rather a form of engaged understanding. (Malcolm 1977; Phillips 1966, 1976; Moore 1997, 2001).

For example, the states of understanding which are constitutive of one's capability to pray or to practise Buddhist meditation, to communicate their religious understanding, or to develop arguments concerning God are not forms of theoretical knowledge of specific states of affairs. They are holistic states of intelligibility of a diversity of possibilities and rules of practices and language which enable one to engage in spiritual practices and to use religious language. This form of holistic knowledge constitutes ineffable religious understanding. ${ }^{3}$

From this perspective, the use of religious language can be reinterpreted and understood as embedded in a religious cultural background, as part of spiritual life. Religious language is not

2 For more details and other relevant references see Baiasu (2014a).

3 In my reading, (or according to my further elaboration) of the Wittgensteinian approach considered here, ineffable understanding makes possible knowledge-how and is not itself a form of knowing how. So this discussion is not concerned with the issue of the effability of knowledge-how, and therefore does not engage with recent debates on this issue. 
primarily used to formulate beliefs or propositional cognitions, but to articulate deep spiritual concerns which are guided by an attempt to find meaning in life, to make sense of things in a way which is connected to spiritual concerns. Religious uses of language can take various forms which are not reducible to expressions of propositional knowledge; they might be, in worship or prayer, for example, expressions of faith, wonder or reverence. They can have various purposes which cannot be reduced to the aims of theoretical argumentation; such purposes can consist, for example, in finding ways of dealing with sorrow, guilt, despair, death or various other aspects of one's life or situations in which one finds oneself.

\section{A Wittgensteinian Solution to the Challenge of Inconsistency}

A recent, Wittgensteinian elaboration of a solution to the inconsistency objection is offered by A. W. Moore (Moore 2001, 2003). Very briefly put, his argument goes something like this. Insofar as ineffable knowledge is a state of understanding which is manifest in one's competence over something and is enacted in engaged forms of making sense of things, it is possible to talk legitimately about it. More specifically, we can describe and discuss how religious texts and practices use language, in unusual, creative ways in order to communicate something ineffable. We can talk about someone's ability to use religious language in that way, that is, about her (ineffable) understanding enabling her to take part in relevant spiritual practices.

We can describe all of this in a detached way, without fully engaging in those linguistic practices. There is nothing contradictory about someone's talking about ineffable understanding in this way. Hence this approach can thus respond to the inconsistency objection.

It is important to note here that this approach uses certain descriptive techniques of dealing with religious knowledge, which involve a detached or disengaged description of certain linguistic practices which exploit language to communicate religious understanding (Phillips 1966). Moreover, it might even be said that this approach aims at truth in the sense that attempts to produce true statements about ineffable understanding (Moore 2001, p. 73).

\section{New Challenges}

The post-metaphysical Wittgensteinian approach is very attractive in many respects. For example, it invites interdisciplinary work: it proposes a descriptive methodology which might be relevant to other disciplines such as religious studies or sociology of religion. Furthermore, and quite significantly for our concerns here, there is a commonality between central features of the Wittgensteinian approach sketched above and dominant characteristics of contemporary feminist philosophical methodology, namely their post-metaphysical and non-foundationalist commitments and the emphasis on the situatedness of knowledge, that is, its embeddedness in life, culture and action. An importantissue I would like to consider now concerns the situatedness of knowledge and the impact of this issue on religious knowledge and the life of knowing subjects.

The view that religious language and life forms are embedded in the religious traditions and life forms in which they have developed can be taken to imply that they function separately from other areas of language and life. Certain Wittgensteinians suggest that they are distinctive forms of language and life, which set their own norms of sense, truth and rationality. Religious life forms and language are considered to be, in this sense, autonomous (Rhees 1969; Malcolm 1960). A religious life form cannot be criticised and evaluated from the outside but only from within that life form. On this view, philosophy can only describe but cannot criticise religious life forms and discourse. One might invoke here Wittgenstein's famous remark in the Philosophical Investigations that philosophy leaves everything as it is (Wittgenstein 1958).

An important criticism of this description-focused post-metaphysical approach points out the lack of normative and critical force of this approach and stresses the importance of philosophy's critical engagement with religious practices and discourses (Nielsen and Phillips 2005). Furthermore, the description-focused approach can cover up unquestioned assumptions. Some of these can 
produce harmful implicit biases. A radical version of this type of criticism can be found in recent feminist philosophy.

One of the most provocative challenges of the Wittgensteinian approach (as well as the traditional approach) concerns the possibility of developing a 'detached description'. If knowledge is situated in some way or another and cannot be detached completely from say, the form of culture in which it is embedded, or from its embodiment and gendering, how is it possible to develop a detached description of that knowledge?

According to a dominant view in feminist epistemology, knowledge is situated in the sense that is produced in relation to a perspective or location which is shaped by one's gender as well as other factors such as culture, historical and social background, race, and power relations (see for example, Haraway 1988; Harding 1986; Alcoff 1996).

Feminist epistemologists point out that gender influences knowledge in many various ways and identify illegitimate gender biases at the core of theoretical knowledge. For example, Rae Langton, for instance, lays out some of the ways 'women are left out' the domain of knowledge: they are left out as objects of study of various disciplines; they may not be counted as fully functioning as knowing subjects; they lack confidence and credibility (Langton 2000). Insofar as women's lives, perspectives and knowledge of the world are not included or marginalised, the production of knowledge can only consist of partial accounts developed from men's perspectives. Furthermore, when it comes to knowledge, Langton points out, women can get hurt. As Miranda Fricker stresses, the unjust distribution of epistemic credibility leads to epistemic injustice (Fricker 2007).

A number of feminists point out the stereotypical association of the masculine and the feminine with different modes of knowing such as, for example, individualistic versus holistic understanding; propositional knowledge versus practical knowledge; logical argument versus narratives/story telling. Stereotypical 'feminine' modes of knowing, such as women's practical knowledge to look after children or the aged are devalued by traditional conceptions of knowledge which prioritise certain epistemic models and ideals that both conceal and reinforce sexist biases. For instance, the privileging of propositional knowledge and logical argument was used to devaluate the practical knowledge of women concerning, for example, child birth and rearing. As Linda Alcoff and Vrinda Dalmiya note, 'traditional women's beliefs_-about childbearing and rearing, herbal medicines, the secrets of good cooking, and such [ ... ] fail to get accorded the honorific status of knowledge' by dominant conceptions of knowledge which take propositional knowledge to be the paradigm of knowledge (Dalmiya and Alcoff 1993, p. 217).

So, the notion of situated knowledge refers, in this context, to the gendering of knowledge, that is, various ways gender influences knowledge and, in particular, the ways it affects the formation and employment of conceptual and methodological models. For example, on this view, a philosopher's approach to a certain topic is situated in the sense that it takes over and uses certain pre-existing conceptual schemes concerning truth, meaning and conditions for speech and argumentation. Feminists point out that the employment of certain privileged, dominant conceptions of knowledge leads to the exclusion or marginalisation of other forms or knowledge such as women's practical forms of knowledge. A philosophical critique of the gendering of knowledge and a reform within epistemic practices are therefore needed for an inclusive epistemology which aims to do justice to the variety and diversity of forms of knowledge. From this feminist perspective, epistemology is concerned not only with theoretical issues but also raises issues of ethics and politics.

It should be noted that many feminists do not claim that all knowledge is gendered, but claim that the gendering of knowledge is much more pervasive and extended than it is acknowledged by mainstream views about knowledge in epistemology.

In recent work in feminist philosophy of religion and theology, thinkers such as Pamela Sue Anderson, Grace Jantzen or Tina Beattie stress in various ways the gendering of religious knowledge and its situatedness or locatedness (Anderson 2012; Beattie 2006; Jantzen 1998). As Jantzen suggests in Becoming Divine: Towards a Feminist Philosophy of Religion, the notion of the 'social locatedness' 
of knowledge which challenges 'the idea of universal rationality as this has been constructed in the western philosophical discourses of modernity' appears to be central to, and shared by, various feminist reconstructions of the project of knowledge and knowledge production (Jantzen 1998, p. 3).

Pamela Sue Anderson explores further the notion of 'epistemic locatedness' or situatedness in relation to religious knowledge in her last book, Revisioning Gender in Philosophy of Religion: Reason, Love and Epistmic Locatedness. ${ }^{4}$ As she points out, an important feature of epistemic locatedness consist in our being situated in a tradition and community of knowers. This is taken to affect philosophers' conceptions of truth, meaning and the conditions of adequate argumentation (Anderson 2012, p. 75). The notion of epistemic locatedness can be used to raise questions about epistemic implicit bias with regard to religious knowledge. Anderson, for example, notes that it could be argued that the Wittgensteinian approach (or, more precisely, some versions of it) might still prioritize the effable and propositional truth which have been traditionally or stereotypically associated with male biased ideas of rationality. From this perspective, 'the wise women's tales' are taken to fail to produce genuine sense and truth (Anderson 2012, p. 85). ${ }^{5}$ Anderson agrees with Jantzen that this view might be seen as demeaning women's spiritual knowledge (Jantzen 1995) although their approaches are significantly different.

To illustrate this point, let me briefly mention an example offered by Vrinda Dalmiya and Linda Alcoff in their piece 'Are Old Wives' Tales' Justified?' (1993). At the beginning of this piece, they recount an episode entitled 'The Devoted Wife' from the ancient Indian spiritual epic The Mahäbhārata (Van Buitenen 1975, Book 3, 37 e and f). The story describes an encounter between a housewife and the sage Kausika; I do not recount it here, but only mention some aspects of it which are of interest in this context. The description of the woman as devoting her life to her husband, family and the Gods 'does not wave any feminist flags!' (Dalmiya and Alcoff 1993, p. 219); the story can, however, be used to illustrate certain important epistemological points. In relation to this, it is important to note the contrast between the two characters. The Brahmin Kausika devoted his life to the study of the Vedas; he is 'master of theoretical knowledge' (p. 219). By contrast, the housewife lacks theoretical knowledge; she devoted her life to her husband, family and the Gods and has a practical understanding of daily life, corresponding to her station in life.

Dalmiya and Alcoff point out that, for Western mainstream epistemology, the account of theoretical propositional knowledge sets strict standards for what can be called knowledge. This view is also dominant in Analytic philosophy of religion. By these standards, housewife's beliefs cannot be granted the status of knowledge, given that she lacks theoretical knowledge.

But in the story, the woman turns out to be spiritually wiser than the Brahmin, who ultimately accepts her epistemic authority; as Dalmiya and Alcoff put it, 'Kausika, the master of theoretical knowledge, has learned the truth from an ordinary and nameless housewife' (p. 219). They raise the question as to what the consequence would be for epistemology if the story's suggestion that the housewife is a genuine epistemic agent were taken seriously. They argue against what they call 'the epistemic discrimination' brought about by mainstream Anglo-American epistemology and, in particular, its focus on propositional and effable knowledge, and propose an inclusive epistemology which incorporates accounts of other forms of knowledge, such as, engaged, practical knowledge and ineffable knowledge as at least equally important. This inclusive approach makes it possible to confer the status of knowledge to modes of understanding traditionally associated with women's daily and spiritual lives.

Let us now go back to Jantzen's and Anderson's approaches to ineffability and gender in philosophy of religion. Jantzen offers a radical feminist approach to gendered religious knowledge.

4 I have discussed related aspects of the notion of situatedness in Baiasu (2009, 2012, 2014b).

5 More specifically Anderson engages in a debate with Adrian W. Moore's Wittgensteinian approach to ineffable knowledge. For his response to Anderson's critical points see (Moore 2020). I have discussed some aspects of their debate in (Baiasu 2014b). 
She suggests that the ineffable has been traditionally associated in the West with the feminine since ancient times. She points out that '[i]n his Metaphysics, Aristotle ascribed to Pythagoras a table of opposites which has had incalculable effects on Western thinking' (Jantzen 1998, p. 266). In this table, women are associated with the infinite and darkness which implies an association with the ineffable; by contrast, men are associated with limit and light, which suggest an association to the orderly and the effable. Jantzen notes that Plato reused these binaries in a number of dialogues and developed them in terms of the association of the male with mind and spirit and the female with body and matter. Jewish and Christian Platonism further associated the mind and maleness with the divine, and the world with matter, chaos and the female, thus constituting the western symbolic which still informs patriarchal cultural frameworks of the social world.

In this view, women's association with ineffability has a negative character: it implies an association to lack or weakness, among other things. By contrast, Jantzen contends, men have been associated with infinity and power. In this view, the ineffable, understood as private experience, has been regarded as an unreliable source of knowledge; by contrast, the drive to infinity has been valorised positively as a source of power linked to the divine. The epistemic drive to infinity involves a desire to be all-knowing and to embody God's eye point of view. But, Jantzen notes, this epistemic drive to infinity has taken various destructive political shapes: totalitarianism was one of its most monstruous enactments, as Hannah Arendt points out in her account of Nazism and the Stalinist regime. Jantzen's criticism is akin to Donna Haraway's critical discussion of the insatiable drive to knowledge, governed by the ideal of the 'view from nowhere' and 'from everywhere', which constitutes fantastic destructive forces affecting not only women, but humanity in general and the world (Haraway 1988).

Jantzen argues for a radical, 'root-and-branch eradication of such valorization of infinity, and its replacement with an acceptance of limits' which has been traditionally associated with women's lives (Jantzen 1995, p. 155). She thus proposes a positive valorization of the finite and argues for an overcoming of the traditional valorization. Her account does not, however, include a reevaluation of the ineffable. In Jantzen's view, the association of the feminine with the ineffable undermines and devalues women's knowledge and, in particular, female mystics' knowledge. Ineffability appears to function as a source of epistemic injustice to women.

Pamela Sue Anderson's more moderate approach includes a critique of certain central views and assumptions of Jantzen's approach; both thinkers share, however, a feminist concern for a positive reevaluation of women's spiritual knowledge and, in particular, their mystical knowledge. Most importantly for my purposes here, Anderson takes issue with Jantzen's understanding of the ineffable. Anderson proposes a defence of ineffability as a rich philosophical resource which has been insufficiently explored in Western philosophy and, more specifically, the analytic and European traditions, and encourages philosophers of religions in both traditions to turn their attention to this central, but often neglected issue in philosophy of religion. Anderson suggests that the philosophical investigation of the ineffable can significantly contribute to the pursuit of epistemic justice for both women and men.

Anderson questions Jantzen's view of the ineffable as private experience and as associated with weakness, unreliability and lack of knowledge (Anderson 2012, p. 76). It is indeed not clear why ineffable knowledge should be considered private insofar as mystics can share, to some extent at least, their ineffable insights by means of creative uses of language or narratives. Anderson rejects Jantzen's binary reading of gender differences in terms of the association of the feminine with the ineffable and of the masculine with infinity. In her view, this reading appears to be oversimplistic and arbitrary. She notes that examples in the history of philosophy can be found which can attest a greater complexity and variation in the gendering of knowledge, ineffability and infinity. For example, at the very beginning of Western philosophy, it seems that Pythagoreans were privileging finitude and were associating it with the masculine (Anderson 2012, pp. 76-77). Anderson notes that although Jantzen is aware of this association, she does not properly account for it. Anderson endorses Le Doeuff's 
argument against 'any straightforward extension of gender-dichotomies from the Pythagorean table to men and women with a variety of social and class background' (Anderson 2012, p. 77; Le Doeuff 1989, pp. 113-14).

It might seem surprising that Jantzen's account makes use of certain binaries if we take into account her methodological commitments concerning the questioning and challenging of traditional binaries which she takes to be philosophically inadequate and politically harmful due to their sustaining masculinist forms of oppression. Furthermore, as Jantzen explicitly states, her feminist project is not concerned with a simple reversal of values and polarities of an oppressive system of thought and action. As she points out, such a reversal cannot undermine an oppressive system. This rather requires a radical dismantling of unquestioned binaries and assumptions sustaining the oppressive system, in order to accommodate diversity and fair relationships.

Perhaps it might be possible to defend Jantzen, at least to some extent, against Anderson's critiques; or, quite on the contrary, perhaps these critiques can be pursued by developing further Anderson's line of argument which points out certain inconsistencies in Jantzen's argumentation demonstrating that perhaps Jantzen's approach was not as radical as Jantzen intended it to be. But it is not my purpose here to carry on further evaluating the debate between Anderson and Jantzen, although this is a very interesting topic for other potential discussions in feminist philosophy of religion. What I would like to point out, in this context, is Anderson's insistence that the ineffable should not be given up too easily and that it is a crucial topic in philosophy in general (which can bring together philosophers from various traditions, including feminist philosophers) and an issue at the heart of philosophy of religion. I could not agree more with this.

If the ineffable is not essentially associated with the feminine is it gender-neutral? In feminists' view, to assume gender-neutrality is, in most cases, to ignore gender and, in this context, to ignore the gendering of knowledge which, as we have seen earlier, can seriously affect in various negative ways knowledge and the lives of knowers. However, feminists like Anderson stress that the story of the gendering of knowledge and, in particular, ineffable knowledge, cannot be told in terms of binary dichotomies, but is much more complex and difficult to tell, insofar as it has to take into account the great variation of its historical, cultural and material locatedness.

\section{Conclusions}

In this paper I pointed out that the issue of ineffability is a significant philosophical epistemic resource at the heart philosophy of religion, which has often been unacknowledged or neglected by mainstream approaches with which certain influential feminist philosophers like Anderson critically engage in their work. I have argued that the issue of ineffability constitutes a major challenge for traditional, metaphysical approaches to religious knowledge. I have considered an alternative, post-metaphysical approach which draws on the later Wittgenstein. This approach seems to offer methodological tools and conceptual resources which appear to be useful when one tries to come to terms with the ineffable. It could be argued that the Wittgensteinian approach has some affinity to influential contemporary feminist views about knowledge. These feminist approaches could also be characterized as post-metaphysical, in the broad sense I sketched in the paper, namely insofar as they point out that religious knowledge is not an abstract or empiricist theorizing about some transcendent or divine reality, but is a cognitive state embedded in religious culture and spiritual practices.

These feminist approaches raise, however, important challenges not only to traditional, metaphysical accounts of religious knowledge but also to the Wittgensteinian approach. I have focused here on a criticism formulated in terms of the feminist notion of epistemic situatedness, and, in particular, the gendering of religious knowledge. For Wittgensteinian philosophers of religion the challenge is whether their post-metaphysical approach to religious knowledge can be defended against the critiques mentioned in the previous section and, if not, whether it can be altered in a way which would make it explicitly sensitive to gender issues in religious epistemology which, as we have seen, have a real impact beyond epistemology, in the realm of religious and everyday life. 
This debate can be a constructive critical exchange beneficial for both feminist philosophers and Wittgensteinians working in the area of philosophy of religion. Such a dialogue can lead to further significant insights into the topic of ineffable knowledge, which is crucial for the understanding of religious knowledge. Furthermore, the investigation of ineffability and, in particular, of ineffable religious knowledge appears to be an important part of the feminist project of dismantling oppressive systems affecting contemporary thinking and life.

Acknowledgments: I am very grateful to Adrian W. Moore, Silvia Jonas, Michael Inwood and the anonymous referee from the journal Religions for their suggestions and comments on earlier versions of this piece. I am greatly indebted to late Pamela Sue Anderson for the discussions we had on a number of issues which are central to this paper.

Conflicts of Interest: The author declares no conflicts of interest.

\section{References}

Alcoff, Linda. 1996. Real Knowing New Versions of the Coherence. Ithaca: Cornell University Press.

Alston, William. 1956. Ineffability. The Philosophical Review 65: 506-22. [CrossRef]

Anderson, Pamela Sue. 1998. A Feminist Philosophy of Religion. Oxford: Blackwell.

Anderson, Pamela Sue. 2002. Ineffable Knowledge and Gender. In Rethinking Philosophy of Religion: Approaches from Continental Philosophy. Edited by Philip Goodchild. New York: Fordham University Press.

Anderson, Pamela Sue. 2012. Re-Visioning Gender in Philosophy of Religion. Reason, Love, and Epistemic Locatedness. London: Ashgate.

Baiasu, Roxana. 2009. Bodies in Space: Transcendence and Spatialisation of Gender. In New Topics in Feminist Philosophy of Religion. Edited by Pamela Sue Anderson. Dordrecht: Springer-Kluwer.

Baiasu, Roxana. 2012. Space and the Limits of Objectivity: Could There Be a Disembodied Thinking of Reality? In Contemporary Kantian Metaphysics: New Essays on Time and Space. Edited by Roxana Baiasu, Graham Bird and Adrian W. Moore. London: Palgrave.

Baiasu, Roxana. 2014a. How is Philosophy supposed to Engage with Religion? The Southern Journal of Philosophy 52: 113-36. [CrossRef]

Baiasu, Roxana. 2014b. Knowing How to Talk about What Cannot be Said: Objectivity and Epistemic Locatedness. Sophia 53: 215-29. [CrossRef]

Beattie, T. 2006. The New Catholic Feminism: Theology, Gender Theory and Dialogue. Oxford: Routledge.

Bennett-Hunter, Guy. 2014. Ineffability and Religious Experience. London and New York: Routledge.

Dalmiya, Vrinda, and Linda Alcoff. 1993. Are "Old Wives Tales" Justified? In Feminist Epistemologies. Edited by Linda Alcoff and Elizabeth Potter. London: Routledge, pp. 217-41.

Derrida, Jacques. 1992. How to Avoid Speaking: Denials. In Derrida and Negative Theology. Edited by Harold Coward and Toby Foshay. Translated by Ken Frieden. Albany: SUNY Press, pp. 73-142.

Derrida, Jacques. 1995. On the Name. Edited by Thomas Dutoit. Translated by David Wood, John P. Leavey, and Ian McLeod. Stanford: Stanford University Press.

Derrida, Jacques. 2001. Response to Moore. In Arguing with Derrida. Edited by Simon Glendinning. Oxford: Blackwell, (also in Ratio: An International Journal of Analytic Philosophy, XIII/4, 2000, pp. 355-81).

Fricker, Miranda. 2007. Epistemic Injustice: Power and the Ethics of Knowing. Oxford: OUP.

Glendinning, Simon. 2001. Arguing with Derrida. Oxford: Blackwell.

Haraway, Donna. 1988. Situated Knowledges: The Science Question in Feminism and the Privilege of Partial Perspective. Feminist Studies 14: 575-600. [CrossRef]

Harding, Sandra. 1986. The Science Question in Feminism. Ithaca: Cornell University Press.

Heidegger, Martin. 1977. 'Letter on Humanism' and 'The Origin of the Work of Art'. In Basic Writings. Edited by David Farrell Krell. New York: Harper \& Row.

Heidegger, Martin. 1992. Phenomenological Interpretations with Respect to Aristotle: Indication of the Hermeneutical Situation. Man and World 25: 355-93.

Heidegger, Martin. 1998. Phenomenology and Theology. In Pathmarks. Edited by William McNeill. Cambridge: Cambridge University Press. 
Heidegger, Martin. 2010. The Phenomenology of Religious Life. Translated by Matthias Fritsch, and Jennifer Anna Gosetti-Ferencei. Bloomington: Indiana University Press.

Jantzen, Grace M. 1995. Power, Gender and Christian Mysticism. Cambridge: CUP.

Jantzen, Grace M. 1998. Becoming Divine: Towards a Feminist Philosophy of Religion. Manchester: Manchester University Press.

Jonas, Silvia. 2016. Ineffability and Its Metaphysics: The Unspeakable in Art, Religion, and Philosophy. New York: Palgrave Macmillan.

Langton, Rae. 2000. Feminism in Epistemology: Exclusion and Objectification. In The Cambridge Companion to Feminism in Philosophy. Edited by Miranda Fricker and Jennifer Hornsby. Cambridge: Cambridge University Press.

Le Doeuff, Michèle. 1989. Long Hair, Short Ideas. In The Philosophical Imaginary. Translated by Colin Gordon. London: The Athlone Press.

Malcolm, Norman. 1960. Anselm's Ontological Arguments. The Philosophical Review 69: 41-62. [CrossRef]

Malcolm, Norman. 1977. The Groundlessness of Religious Beliefs. In Thought and Knowledge. Ithaca: Cornell University Press.

Marion, Jean-Luc. 1999. In the Name: How to Avoid Speaking of 'Negative Theology'. In God, the Gift and Postmodernism. Edited by John D. Caputo and Michael J. Scanlon. Bloomington: Indiana University Press.

Moore, Adrian W. 1997. Points of View. Oxford: OUP.

Moore, Adrian W. 2001. Arguing with Derrida. In Arguing with Derrida. Edited by Simon Glendinning. Oxford: Blackwell, (also in Ratio: An International Journal of Analytic Philosophy, XIII/4, 2000, pp. 355-81).

Moore, Adrian W. 2003. Ineffability and Religion. European Journal of Philosophy 11: 161-76. [CrossRef]

Moore, Adrian W. 2020. The Concern with Truth, Sense, et al. Angelaki 22. forthcoming.

Nielsen, Kai, and Dewi Zephaniah Phillips, eds. 2005. Wittgensteinian Fideism. London: SCM Press.

Phillips, Dewi Zephaniah. 1966. Concept of Prayer. New York: Schocken Books.

Phillips, Dewi Zephaniah. 1976. Religion without Explanation. Oxford: Blackwell.

Rhees, Rush. 1969. Withouth Answers. London: Routledge.

J. A. B. Van Buitenen, trans. and ed. 1975, The Mahabharata. Chicago: University of Chicago Press.

Wittgenstein, Ludwig. 1958. Philosophical Investigations. Translated by G. E. M. Anscombe. Oxford: Blackwell.

(C) 2018 by the author. Licensee MDPI, Basel, Switzerland. This article is an open access article distributed under the terms and conditions of the Creative Commons Attribution (CC BY) license (http:/ / creativecommons.org/licenses/by/4.0/). 